\title{
Does grip strength predict lower limb global strength in subjects with stroke?
}

\author{
Força de preensão relaciona-se com força de membros \\ inferiores pós-acidente vascular encefálico?
}

\author{
Fuerza de asimiento y fuerza de miembros inferiores \\ después del accidente cerebrovascular
}

Juliane Franco $₫$, Ludmylla Ferreira Quintino $®$, Christina Danielli Coelho de Morais Faria $₫ *$

Universidade Federal de Minas Gerais (UFMG), Belo Horizonte, Brazil

\begin{abstract}
Introduction: Grip strength is an important clinical measure and has been used for several purposes in different populations, including those to predict the global strength of lower limbs (LL) and upper limbs. However, little is known about the association between grip strength and lower limb (LL) global strength in subjects with stroke. Objective: To investigate the relationship between grip strength and LL global strength in stroke with subjects at both subacute and chronic phases. Method: Measures of grip strength (handgrip dynamometer) and LL global strength (hand-held dynamometer) were obtained in 20 subjects in the subacute phase of the stroke and 18 in the chronic phase. Pearson correlation coefficient was used to investigate the correlation between grip strength and LL global strength $(\alpha=0.05)$. Results: Subjects in the subacute phase showed a moderate statistically significant correlation between paretic grip strength and global strength of the non-paretic LL $(r=0.50 ; p<0.05)$, but no correlation with the paretic LL was
\end{abstract}

* JF: MS, e-mail: julianef_@hotmail.com LFQ: MS, e-mail: ferreiraquintino@hotmail.com CDCMF: PhD, e-mail: cdcmf@ufmg.br 
found $(p=0.25)$. The non-paretic grip strength showed no statistically significant correlation with global strength of the paretic LL ( $p=0.93)$ and of the non-paretic LL ( $p=0.64)$. In chronic subjects, no statistically significant correlation $(0.50 \leq p \leq 0.97)$ was observed. Conclusion: Grip strength does not seem to be an adequate indicator to predict LL global strength of subjects with stroke. This conclusion is different from that obtained for other populations.

Keywords: Stroke. Hand Strength. Muscle Strength. Lower Extremity. Disability Evaluation.

\section{Resumo}

Introdução: A força de preensão palmar (FPP) é uma importante medida clínica e vem sendo utilizada com diversos propósitos em diferentes populações, dentre eles para predizer a força global de membros inferiores (MMII) e superiores. Entretanto, pouco se sabe sobre a associação da FPP e força global de MMII pós-Acidente Vascular Encefálico (AVE). Objetivo: Investigar a relação entre FPP e força global de MMII em indivíduos pós-AVE, nas fases subaguda e crônica. Método: Foram incluídos 38 indivíduos pós-AVE (20 subagudos/18 crônicos). A FPP foi avaliada pelo dinamômetro de preensão palmar e a força global de MMII pelo dinamômetro portátil. Coeficiente de correlação de Pearson foi calculado para investigar a correlação entre FPP e força global de MMII $(\alpha=0,05)$. Resultados: Para os indivíduos da fase subaguda do AVE, foi observada correlação estatisticamente significativa entre FPP do lado parético e força global de MI do lado não-parético ( $r=0,50$; $p<0,05)$. Para o MI parético não houve correlação significativa $(p=0,25)$. Para FPP do lado não-parético, não foi observada correlação estatisticamente significativa com a força global de MMII tanto para o lado parético $(p=0,93)$ quanto para o não-parético $(p=0,64)$. Nos indivíduos crônicos, não foi observada nenhuma correlação estatisticamente significativa $(0,50 \leq p \leq 0,97)$. Conclusão: A FPP parece não ser uma medida adequada para informar sobre a força global de MMII pós-AVE, diferentemente do observado em outras populações.

Palavras-chave: Acidente Vascular Cerebral. Força da Mão. Força Muscular. Extremidade Inferior. Avaliação da Deficiência.

\section{Resumen}

Introducción: La fuerza de prensión de la mano (FPM) es una medida clínica importante y se viene usando con diversos propósitos en diferentes poblaciones, entre ellos para predecir la fuerza global de miembros inferiores (MI) y superiores. Sin embargo, poco se sabe acerca de la asociación entre la FPM y la fuerza global de los MI después del accidente cerebrovascular (ACV). Objetivo: Investigar la relación entre la FPM y la fuerza global de MI en sujetos después del ACV, en las fases subaguda y crónica. Método: Se obtuvieron medidas de la FPM con el dinamómetro hidráulico, de la fuerza global de MI con el dinamómetro digital, de 20 sujetos subagudos y 18 sujetos crónicos después del ACV. El coeficiente de correlación de Pearson se calculó para investigar la correlación entre la FPM y la fuerza global de MI $(\alpha=0,05)$. Resultados: Para los sujetos de la fase subaguda del ACV, se observó una correlación estadísticamente significativa entre FPM del lado parético y fuerza global de MI del lado no parético ( $r=0,50 ; p<0,05)$. Para el MI parético no hubo correlación significativa $(p=0,25)$. Para FPM del lado no parético, no se observó correlación estadísticamente significativa con la fuerza global de MI tanto para el lado parético $(p=0,93)$ como para el no parético $(p=0,64)$. Entre los sujetos crónicos, no se observó ninguna correlación estadísticamente significativa $(0,50 \leq p \leq 0,97)$. Conclusiones: La FPM no parece ser una medida adecuada para informar sobre la fuerza global de MI en sujetos después del ACV, a diferencia de lo observado con otras poblaciones.

Palabras clave: Accidente Cerebrovascular. Fuerza de la Mano. Fuerza Muscular. Extremidad Inferior.

Evaluación de la Discapacidad. 


\section{Introduction}

Stroke is the leading cause of disability in developed and developing countries [1-3], being associated with important emotional and socioeconomic impacts $[1,3]$. Despite the higher prevalence in older adults [4], its incidence have increased significantly in younger individuals [1], which, consequently, generates an increase in early retirement expenses and broadens the burden of stroke [3]. Therefore, stroke is a major non-communicable disease for public health [3].

Muscular weakness is one of the main poststroke impairments [5, 6] being an important factor for motor disability in these individuals [7, 8]. Moreover, in post-stroke individuals, weakness of the lower limb muscles is associated with limited ability to perform daily living activities [8]. Recovering the independence to perform important functional activities such as sit-to-stand/stand-to-sit tasks $[9,10]$, walking up the stairs [6] and community gait $[8,11,12]$ is a key goal, playing an important role in rehabilitation of post-stroke individuals. Thus, the measure of muscle strength is a relevant outcome that should be one of the pillars of the evaluation and rehabilitation process of these individuals.

Post-stroke individuals are classified according to typical stages of spontaneous motor recovery, which are determined based on the time at which important biological neural repair processes occurs $[13,14]$. This recovery could be complete or incomplete, being directly related to the sequelae of the event such as loss of muscle strength and functional limitations [13]. Therefore, physical therapist's clinical management and rehabilitation processes should consider the typical phases of post-injury progress, as each phase is associated with specific response patterns. For example, the spontaneous motor recovery process is more intense in the acute phase, progressing to stabilization in the chronic phase $[13,14]$

Grip strength is an important clinical measure. This measure has been used for several purposes in different populations [15-18]. Garcia et al. [17] conducted a cross-sectional study to evaluate the relationship between different clinical measures of community-dwelling older adults and identify the best clinical parameter to screen reduced lowerlimb muscle function in this population. The clinical measures evaluated in this study were lower extremity muscle function, calf circumference, grip strength, functional mobility and level of physical activity [17].
The results showed an association between lowerlimb muscle function, grip strength and fast walking speed, suggesting the possibility of screening and identification of minor functional changes through simple clinical measures, as grip strength. This may favor early intervention and prevent disabilities in community-dwelling older adults with high activity levels [17].

Considering that the association between grip strength and lower-limb muscle function has been proved to be a relevant parameter to be investigated in older adult population [17], investigating this association in different populations with muscle weakness and disabilities becomes necessary. In this context, post-stroke individuals must be considered, since this population commonly present lower thresholds for muscle fatigue as well as muscle weakness $[12,19]$. Thus, a fast and objective measure such as grip strength would optimize the clinical evaluation process by informing about lower-limb global strength. The use of this measure indicator would reduce not only strain on patients and professionals but also time and cost of evaluation when compared with extensive evaluations of different muscle groups. However, the effectiveness of the grip strength of subacute and chronic poststroke individuals to inform about the lower-limb global strength is still unclear, as it has been used in the older adults [17].

Considering: a) the importance of muscle strength assessment-especially grip strength and lower-limb strength-for the rehabilitation process of post-stroke individuals; and b) the need of a fast and objective measurement that optimizes the clinical evaluation process and, consequently, generates less strain and costs for patients and professionals when compared with extensive evaluations of different muscle groups. Our study sought to investigate the relationship between grip strength and lower-limb global strength in individuals with stroke at both subacute and chronic phases.

\section{Methods}

\section{Design and participants}

This cross-sectional study [20], approved by Research Ethical Committee of the Universidade Federal de Minas Gerais, Belo Horizonte, Minas Gerais, Brazil (ETIC 0492.0.203.000-10) was conducted in 
a university laboratory, participants' households, and community-based settings. Participants were selected from the general community by contact with professionals from outpatient clinics, rehabilitation centers, as well as from database of previously conducted research projects. The inclusion criteria were: clinical diagnosis of stroke between 3 and 6 months prior to de study (subacute phase), and more than 6 months prior to the study (chronic phase); age $\geq 20$ years; and ability to execute all tests. The exclusion criteria were: presence of possible cognitive deficits identified by the Mini Mental State Examination, cut-off scores according to schooling levels (i.e. illiterate: 13 points; $1-7$ years of education: 18 points; 8 or more years of schooling: 26 points) [21]; reports of any health condition that could compromise the strength lower-limbs and/ or grip muscles; and complaints of pain during the assessment procedures.

All participants signed an Informed Consent Form based on the previous approval of the Research Ethical Committee of the University.

\section{Sample size}

$\mathrm{G}^{*}$ Power software [22] was used to determine the sample size of individuals in subacute phase, considering a power $=0,8, r=0,6$ e $\alpha=0,05$. Data from Tavares et al. [19] and Faria et al. [23] were considered to determine the sample size of individuals in the chronic phase, considering correlation coefficient. It was found that 20 post-stroke individuals in the subacute phase and 18 in the chronic phase would be needed.

\section{Outcome measures}

Bilateral measures of grip strength and of seven lower-limb muscle groups were obtained (hip flexors/extensors/abductors, knee flexors/extensors, ankle dorsiflexors/plantar flexors). Strength of the grip strength and of lower-limb muscles were measured, respectively, by a hydraulic SAEHAN ${ }^{\circledR}$ grip dynamometer (Model SH5001; SAEHAN Corporation, YangdeokDong, Masan, South Korea) as shown in Figure 1 and by a microFET2 ${ }^{\circledR}$ digital handheld dynamometer (Hoggan Health Industries, Inc, Draper, Utah, USA) (Figure 2). Both equipment devices are considered clinical gold standard methods for the assessment of isometric strength [24] and have adequate values of measurement properties for assessing the muscular strength of post-stroke individuals $[19,24]$. The accuracy of both equipment is within $1 \%$ of reading $[25,26]$. All equipment used were purchased factory-calibrated for the completion of our study and were used according to the manufacturer's instructions.

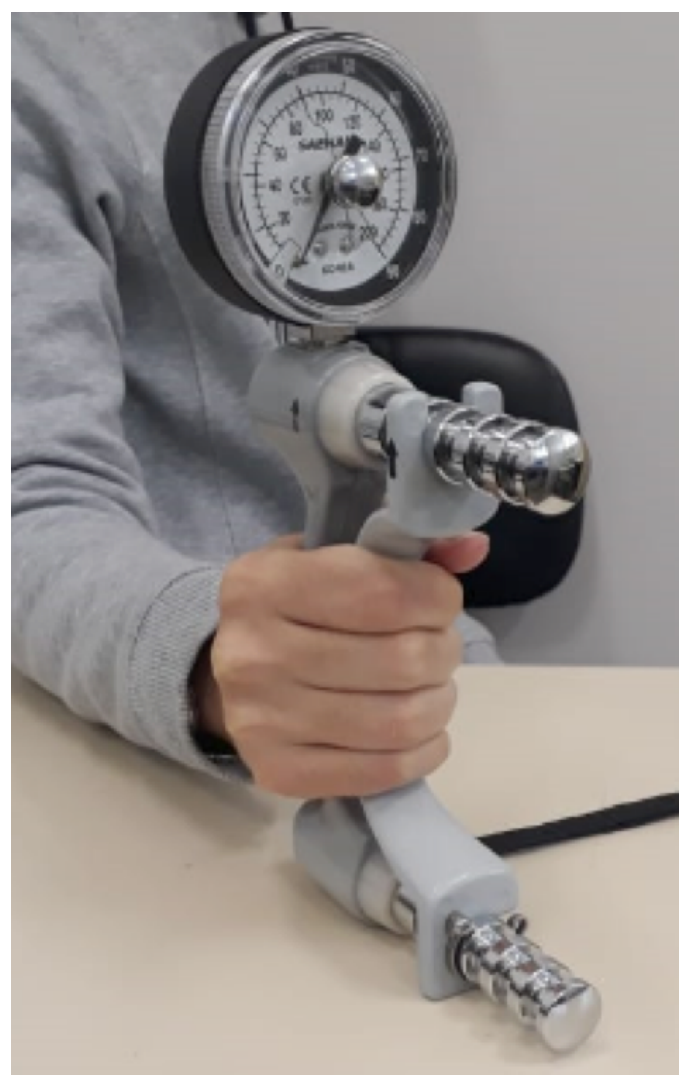

Figure 1-Hydraulic SAEHAN® grip dynamometer.

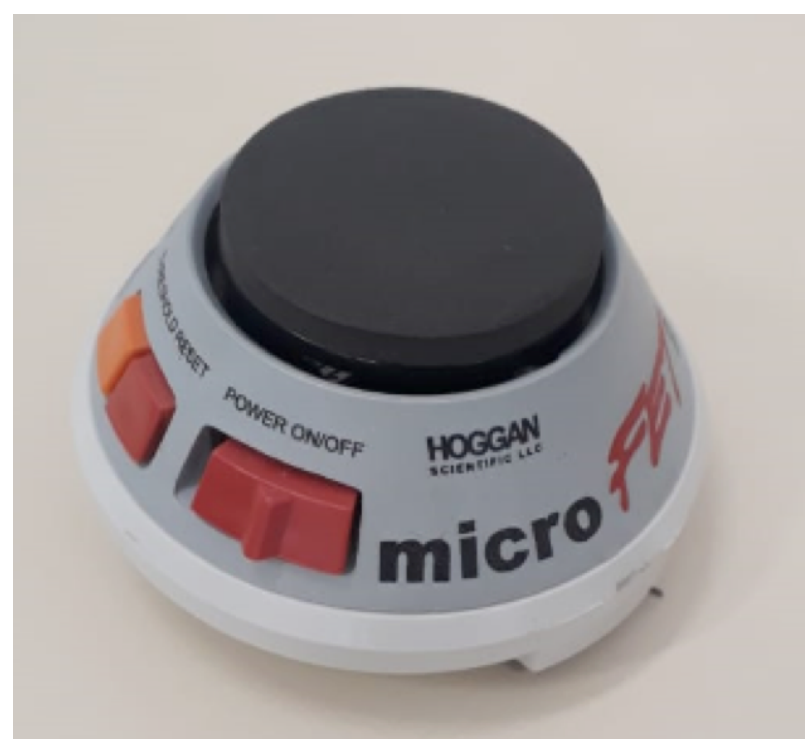

Figure 2 - MicroFET2 ${ }^{\circledR}$ digital handheld dynamometer. 
Procedures

Data were collected on a single day by a trained examiner, who is a physical therapist with one-year experience in muscle strength measurements. First, demographic and clinical data were collected for all individuals (i.e. gender, age, body mass index, and motor impairments: Fulg-Meyer Motor Assessment Scale [27]). All participants were classified according to their physical activity level: vigorous, moderate, insufficient or sedentary. This classification was based on estimated metabolic cost of physical activity based on gender, age, frequency, duration and type of activity performed within the month preceding data collection [28].

Then, muscle strength was assessed. All muscle groups were assessed alternately, with each muscle group of the non-paretic side evaluated first, followed by that of the paretic side. The participants and their body segments were standardized positioned, according to previous protocols [15, 19, 29-31], as shown in Table 1.

Table 1 - Positioning, stabilization, and device application

\begin{tabular}{|c|c|c|c|c|}
\hline Muscle group & Participant's position & Position of the segment & Position of the device & Stabilization \\
\hline Hip flexors & Supine & $\begin{array}{l}\text { Hip and knee flexed to } \\
90^{\circ} \text { and ankle in neutral } \\
\text { position }\end{array}$ & $\begin{array}{l}\text { Distal and anterior aspect } \\
\text { of the thigh }\end{array}$ & None \\
\hline Hip extensors & Supine & $\begin{array}{l}\text { Hip and knee to } 90^{\circ} \text { and } \\
\text { ankle in neutral position }\end{array}$ & $\begin{array}{l}\text { Distal and posterior } \\
\text { aspect of the thigh }\end{array}$ & None \\
\hline Hip abductors & Supine & $\begin{array}{l}\text { Hip in neutral and knee } \\
\text { extended }\end{array}$ & $\begin{array}{l}\text { Distal and lateral aspect } \\
\text { of the thigh }\end{array}$ & None \\
\hline Plantar flexors & Supine & $\begin{array}{l}\text { Hip and knee to } 90^{\circ} \text { and } \\
\text { ankle in neutral position }\end{array}$ & $\begin{array}{l}\text { Proximal to } \\
\text { metatarsophalangeal } \\
\text { joints on the plantar } \\
\text { surfaces }\end{array}$ & $\begin{array}{l}\text { Distal and anterior aspect } \\
\text { of the leg }\end{array}$ \\
\hline Ankle dorsiflexors & Supine & $\begin{array}{l}\text { Hip and knee extended } \\
\text { and ankle in neutral } \\
\text { position }\end{array}$ & $\begin{array}{l}\text { Proximal to } \\
\text { metatarsophalangeal } \\
\text { joints on the dorsal } \\
\text { surfaces }\end{array}$ & $\begin{array}{l}\text { Distal and anterior aspect } \\
\text { of the leg }\end{array}$ \\
\hline Knee flexors & Seated & Hip and knee flexed to $90^{\circ}$ & $\begin{array}{l}\text { Distal and posterior } \\
\text { aspect of the leg }\end{array}$ & $\begin{array}{l}\text { Distal and posterior } \\
\text { aspect of the leg }\end{array}$ \\
\hline Knee extensors & Seated & Hip and knee flexed to $90^{\circ}$ & $\begin{array}{l}\text { Distal and anterior aspect } \\
\text { of the leg }\end{array}$ & $\begin{array}{l}\text { Distal and anterior aspect } \\
\text { of the leg }\end{array}$ \\
\hline Handgrip & Seated & $\begin{array}{l}\text { Shoulder adducted, elbow } \\
\text { flexed to } 90^{\circ} \text {, forearm } \\
\text { in neutral position, wrist } \\
\text { with } 0 \text { to } 30^{\circ} \text { extension }\end{array}$ & Palm of the hand & $\begin{array}{l}\text { Distal aspect of the } \\
\text { forearm }\end{array}$ \\
\hline
\end{tabular}

Immediately before the measurement of muscle strength, the procedures were performed for demonstration and familiarization [8]. Three trials of each assessed muscle groups were performed. During the tests, the individuals were instructed to perform a maximum isometric contraction for 5 seconds, and the peak value was recorded. A 20-second rest interval was allowed between the trials [19, 29, 31]. Participants received the following verbal encouragement: “Go, go, go, go...” [19, 29]. The measures were read and recorded by a second examiner, who was also previously trained $[19,29]$.

To prevent the participant from changing position frequently for the tests, the evaluation of the muscle groups was performed in the same sequence: hip flexors/extensors/abductors, ankle dorsiflexors/plantar flexors, knee flexors/extensors and handgrip strength.

\section{Statistical analysis}

Descriptive statistics and test of normality (Shapiro-Wilk test) were performed for all variables. After, the lower-limb global strength was determined by the sum of the muscle strength values of the hip flexors/extensors/abductors, knee flexors/ extensors, ankle dorsiflexors/plantar flexors. Pearson correlation coefficients were calculated to 
investigate the associations between grip strength and lower-limb global strength. When the coefficient values were statically significant, the magnitudes of the correlations were classified as follows: very weak, $\leq$ 0.25; weak, 0.26-0.49; moderate, 0.50-0.69; strong, 0.70-0.89; and very strong, 0.90-1.00 [32]. All analyses were performed using the SPSS statistical package (SPSS Inc, Chicago IL, USA, 17.0), with a $\leq 0.05$ significance level.

\section{Results}

Twenty post-stroke individuals at subacute phase ( 10 men e 10 women) and 18 post-stroke individuals at chronic phase (12 men and six women) were eligible and participated of the study. Mean age of individuals at subacute phase was 64 years, ( $S D=11.94)$, and mean time since the onset of stroke was three months $(\mathrm{SD}=0.69)$. Mean age of individuals at chronic phase was 58 years $(S D=15.43)$, and mean time since the onset of stroke was 102 months ( $S D=89.95$ ). Regarding the type of stroke, individuals from both subacute and chronic phase had mostly ischemic events. Considering the physical activity level, all individuals at subacute phase and most of the individuals at chronic phase were classified as inactive. Clinical and demographic characteristics of the participants are described in Table 2.

Table 2 - Clinical and demographic characteristic of the sample

\begin{tabular}{|c|c|c|}
\hline Characteristics & $\begin{array}{l}\text { Subacute } \\
(n=20)\end{array}$ & $\begin{array}{l}\text { Chronic } \\
(n=18)\end{array}$ \\
\hline Age (years): mean \pm SD [min-max] & $64.05 \pm 11.94[36-85]$ & $58.50 \pm 15.43[30-86]$ \\
\hline $\begin{array}{l}\text { Time since the onset of stroke (months): } \\
\text { mean } \pm S D \text { [min-max] }\end{array}$ & $3.0 \pm 0.69[3-5]$ & $102.89 \pm 89.95[7-370]$ \\
\hline $\begin{array}{l}\text { Body mass index }\left(\mathrm{kg} / \mathrm{m}^{2}\right) \text {, mean } \pm \mathrm{SD} \\
\text { [min-max] }\end{array}$ & $25.49 \pm 4.21[18.71-36.66]$ & $26.29 \pm 3.48$ [21.74-33.84] \\
\hline Sex: Men, $n(\%)$ & $10(50)$ & $18(75)$ \\
\hline Paretic side: right, n (\%) & $14(53.8)$ & $9(25)$ \\
\hline \multicolumn{3}{|l|}{ Type of stroke: $n$ (\%) } \\
\hline Ischemic & $19(73.1)$ & $13(72.25)$ \\
\hline Hemorrhagic & $1(3.8)$ & $2(11.1)$ \\
\hline Both, Ischemic and Hemorrhagic & - & $1(5.55)$ \\
\hline $\begin{array}{l}\text { Not reported } \\
\text { Fulg-Meyer: }(0-100), n(\%)\end{array}$ & - & $2(11.1)$ \\
\hline Mild motor impairment & $7(35)$ & $3(16.6)$ \\
\hline Moderately motor impairment & $11(55)$ & $5(27.7)$ \\
\hline Moderately Severe motor impairment & $2(10)$ & $9(50.15)$ \\
\hline Very Severe motor impairment & - & $1(5.55)$ \\
\hline \multicolumn{3}{|l|}{ Physical activity level: $n$ (\%) } \\
\hline Vigorous active & - & $1(5.6)$ \\
\hline Moderate active & - & - \\
\hline Insufficient & - & $4(22.1)$ \\
\hline Inactive & $20(100)$ & $13(72.3)$ \\
\hline
\end{tabular}

Note: $\mathrm{SD}=$ standard deviation.

As shown in Table 3, only the grip strength of the paretic side showed moderate significant correlations with the lower-limb global strength of non-paretic side of post-stroke individuals at subacute phase $(r=0.50 ; p<0.05)$. We could not find any other significant correlation $(0.25 \leq p \leq 0.97)$. 
Table 3 - Correlation coefficients between the measurements of grip strength and variables related to lower-limb global strength of post-stroke individuals in subacute $(n=20)$ and chronic $(n=18)$ phases.

\begin{tabular}{lll}
\hline Variables & $\begin{array}{l}\text { Global strength of } \\
\text { paretic lower-limb }\end{array}$ & $\begin{array}{l}\text { Global strength } \\
\text { of non-paretic } \\
\text { lower-limb }\end{array}$ \\
\hline $\begin{array}{l}\text { Subacute phase } \\
\text { rip strength of } \\
\text { non-paretic side } \\
\begin{array}{l}\text { Grip strength of } \\
\text { paretic side }\end{array}\end{array}$ & $p=0.93$ & $p=0.64$ \\
$\begin{array}{l}\text { Chronic phase } \\
\text { Grip strength of } \\
\text { non-paretic side } \\
\text { Grip strength of } \\
\text { paretic side }\end{array}$ & $p=0.25$ & \\
\hline
\end{tabular}

Note: $r=$ Pearson correlation coefficient.

\section{Discussion}

Our study sought to investigate the relationship between grip strength and lower-limb global strength in individuals with stroke at both subacute and chronic phases. For the individuals at the subacute phase, we found a moderate correlation between the grip strength of the paretic side and the lower-limb global strength of the non-paretic side. However, regarding the grip strength of the non-paretic side, we could not observe any significant correlation between the grip strength and the lower-limb global strength, neither for the paretic or non-paretic side. For the post-stroke individuals at the chronic phase, we could not observe any significant correlation between the grip strength and the lower-limb global strength, both for the paretic and non-paretic side.

The results regarding the absence of significant correlation between most of the investigated variables differs from the results reported by previous studies performed in other populations: the grip strength has already been significantly correlated to the lower-limb global strength of children, adolescents, adults and older adults [15-18]. A possible explanation for this disagreement in results is the fact that post-stroke individuals have muscular strength deficits correlated, primarily, to a neurological disorder [33, 34], which is not observed in the populations aforementioned. Moreover, stroke commonly causes sensitive, cognitive and coordination alterations, spasticity, abnormal movement patterns, physical deconditioning and a sedentary lifestyle $[33,35]$. Thus, the particularities associated to the origin and maintenance of the muscular weakness in these individuals might explain the absence of significant correlation between grip strength and most of the variables of our study related to the lower-limb global strength.

The fact that we found a moderate correlation between the grip strength of the paretic side and the lower-limb global strength of the non-paretic side in post-stroke individuals at the subacute phase is an important result. The possibility of assessment only of the grip strength of the paretic side to inform about the lower-limb of the non-paretic side might be useful to optimize clinical evaluation time of these individuals, considering that muscle strength assessment is a relevant outcome and should be considered during the process of rehabilitation of these individuals. Therefore, a concise evaluation not only requires less time, but also reduces the possibility of causing pain and fatigue, especially considering the low muscular fatigue threshold of post-stroke individuals $[15,19]$.

Immediately after a stroke, the central nervous system goes through a complex and dynamic process of anatomical and functional reorganization, which results in a spontaneous motor recovery, that, in general, occurs markedly at the first three months (acute phase), but also is present between the third and sixth months after stroke (subacute phase). Thus, spontaneous motor recovery reaches a plateau at six months (chronic phase) $[13,14]$. Thereby, although classified as a unique population group, the poststroke individuals present particularities regarding each phase of recovery, which could impact on muscle strength measurement and in the functional performance [36]. These particularities can explain the differences observed in the results of our study when analysing the correlations considering muscle strength of post-stroke individuals at the subacute phase and post-stroke individuals at the chronic phase.

Most of the participants in our study was classified as inactive when considered the level of physical activity. This is a relevant data, since physical activity practice is a fundamental component for the maintenance and improvement of the functional status, assisting in the prevention of secondary disabilities [37], in the promotion of health and functionality, besides being an important factor that directly influences the recovery and maintenance of muscle strength [38]. The physical deconditioning, 
caused by inactivity, is a common finding in poststroke individuals, and the high energetic cost presented by this population during daily life activities might contribute to the muscle weakness [35]. Thus, physical inactivity observed in the sample of our study, associated with alterations caused by the physical deconditioning of post-stroke individuals, reinforces the possible explanations previously mentioned for the absence of the correlation between grip strength and most of the other variables related to lower-limb global strength.

A limitation of our study was that most of the participants was classified as inactive, which is commonly observed in post-stroke individuals $[33,35]$. This fact might influence on the relationship between grip strength and lower-limb global strength in this population, since the level of physical activity might directly affect the muscle strength. Thus, individuals with levels of physical activity different from inactive could present results different from those found in our study, and, therefore, these individuals must be included in future studies regarding the relationship between grip strength and lower-limb global strength of post-stroke individuals at the subacute and chronic phase. Although the sample size estimated was achieved, future studies, with larger samples, representing the population of individuals with a more active level of physical activity should be developed to identify if the measure of the strength of only one muscle such as grip strength could predict lower-limb global strength.

\section{Conclusion}

Only grip strength of the paretic side showed potential to moderately predict the lower-limb global strength, specifically the global strength of the lower limb of the non-paretic side of post-stroke individuals at the subacute phase. The results of our study indicate that grip strength, in general, does not seem to be adequate to predict lower-limb global strength in the post-stroke population, in both subacute and chronic phases, differently from that observed in other populations.

\section{Acknowledgements}

Financial support for this study was provided by CAPES (Coordenação de Aperfeiçoamento de Pessoal de Nível Superior - Finance code: 001),
FAPEMIG (Fundação de Amparo à Pesquisa do Estado de Minas Gerais), CNPq (Conselho Nacional de Desenvolvimento Científico e Tecnológico) and PRPq/ UFMG (Pró-reitoria de Pesquisa da Universidade Federal de Minas Gerais).

\section{References}

1. Feigin VL, Norrving B, Mensah GA. Global burden of stroke. Circ Res. 2017;120(3):439-48.

2. Benjamin EJ, Virani SS, Callaway CW, Chamberlain AM, Chang AR, Cheng S, et al. Heart disease and stroke statistics - 2018 update: a report from the American heart association. Circulation. 2018;137(12):e67-492.

3. World Health Organization. Neurological disorders: a public health approach. In: World Health Organization. Neurological disorders: public health challenges. Geneva; 2006. p. 41-176.

4. Mendes EV. Health care networks. Cienc Saude Colet. 2010;15(5):2297-305.

5. Dorsch S, Ada L, Canning CG. Lower limb strength is significantly impaired in all muscle groups in ambulatory people with chronic stroke: a cross-sectional study. Arch Phys Med Rehabil. 2016;97(4):522-7.

6. Park KH, Kim DY, Kim TH. The effect of step climbing exercise on balance and step length in chronic stroke patients. J Phys Ther Sci. 2015;27(11):3515-8.

7. Barbosa DD, Trojahn MR, Porto DVG, Hentschke GS, Hentschke VS. Strength training protocols in hemiparetic individuals post stroke: a systematic review. Fisioter Mov. 2018;31:e003127.

8. Aguiar LT, Camargo LBA, Estarlino LD, TeixeiraSalmela LF, Faria CDCM. Strength of the lower limb and trunk muscles is associated with gait speed in individuals with sub-acute stroke: a cross-sectional study. Braz J Phys Ther. 2018;22(6):459-66.

9. Silva PF, Quintino LF, Franco J, Faria CD. Measurement properties and feasibility of clinical tests to assess sit-to-stand/stand-to-sit tasks in subjects with neurological disease: a systematic review. Braz J Phys Ther. 2014;18(2):99-110. 
10. Silva PF, Quintino LF, Franco J, Rodrigues-de-Paula F, Albuquerque de Araújo P, Faria CDCM. Trunk kinematics related to generation and transfer of the trunk flexor momentum are associated with sit-to-stand performance in chronic stroke survivors. NeuroRehabilitation. 2017;40(1):57-67.

11. Mentiplay BF, Tan D, Williams G, Adair B, Pua YH, Bower KJ, Clark RA. Assessment of isometric muscle strength and rate of torque development with hand-held dynamometry: test-retest reliability and relationship with gait velocity after stroke. J Biomech. 2018;75:171-5.

12. Mentiplay BF, Adair B, Bower KJ, Williams G, Tole G, Clark RA. Associations between lower limb strength and gait velocity following stroke: a systematic review. Brain Inj. 2015;29(4):409-22.

13. Bernhardt J, Hayward KS, Kwakkel G, Ward NS, Wolf SL, Borschmann K, et al. Agreed definitions and a shared vision for new standards in stroke recovery research: The Stroke Recovery and Rehabilitation Roundtable taskforce. Int J Stroke. 2017;12(5):444-50.

14. Bernhardt J, Borschmann K, Boyd L, Thomas Carmichael S, Corbett D, Cramer SC, et al. Moving rehabilitation research forward: developing consensus statements for rehabilitation and recovery research. Int J Stroke. 2016;11(4):454-8.

15. Martins JC, Aguiar LT, Lara EM, Teixeira-Salmela LF, Faria CDCM. Assessment of grip strength with the modified sphygmomanometer test: association between upper limb global strength and motor function. Braz J Phys Ther. 2015;19(6):498-506.

16. Wind AE, Takken T, Helders PJ, Engelbert RH. Is grip strength a predictor for total muscle strength in healthy children, adolescents, and young adults?. Eur J Pediatr. 2010;169(3):281-7.

17. Garcia PA, Dias JMD, Dias RC, Santos P, Zampa CC. Estudo da relação entre função muscular, mobilidade funcional e nível de atividade física em idosos comunitários. Braz J Phys Ther. 2011;15(1):15-22.

18. Cumming TB, Packer M, Kramer SF, English C. The prevalence of fatigue after stroke: a systematic review and meta-analysis. Int J Stroke. 2016;11(9):968-77.
19. Aguiar LT, Martins JC, Lara EM, Albuquerque JA, Teixeira-Salmela LF, Faria CDCM. Dynamometry for the measurement of grip, pinch, and trunk muscles strength in subjects with subacute stroke: reliability and different number of trials. Braz J Phys Ther. 2016;20(5):395-404.

20. Portney LG, Watkins MP. Foundations of clinical research: applications to practice. 3rd ed. Upper Saddle River: Pearson/Prentice Hall; 2015.

21. Bertolucci PHF, Brucki SMD, Campacci SR, Juliano Y. The Mini-Mental State Examination in an outpatient population: influence of literacy. Arq. Neuro-Psiquiatr. 1994;52(1):1-7.

22. Faul F, Erdfelder E, Buchner A, Lang AG. Statistical power analyses using $\mathrm{G}^{*}$ Power 3.1: tests for correlation and regression analyses. Behav Res Methods. 2009;41(4):1149-60.

23. Faria CDCM, Aguiar LT, Lara EM, Souza LAC, Martins JC, Teixeira-Salmela LF. Dynamometry for the assessment of grip, pinch, and trunk strength in subjects with chronic stroke: reliability and various sources of outcome values. Int J Phys Med Rehabil. 2013;1(8):1-5.

24. Stark T, Walker B, Phillips JK, Fejer R, Beck R. Handheld dynamometry correlation with the gold standard isokinetic dynamometry: a systematic review. PM R. 2011;3(5):472-9.

25. Hoggan Health Industries. MicroFET2 User Guide. Salt Lake City, UT: Hoggan Scientific; 2010.

26. Saehan Corporation. Hydraulic hand dynamometer, SH5001: Operating Manual. Masan, South Korea.

27. Maki T, Quagliato EMAB, Cacho EWA, Paz LPS, Nascimento NH, Inoue MMEA, Viana MA. Reliability study on the application of the Fugl-Meyer Scale in Brazil. Braz J Phys Ther. 2006;10(2):177-83.

28. Center for disease control and prevention (CDC). Physical activity trends - United States, 1990-1998. MMWR Morb Mortal Wkly Rep. 2001;50(9):166-9. 
29. Souza LA, Martins JC, Teixeira-Salmela LF, Lara EM, Moura JB, Aguiar LT, Morais Faria CD. Validity and reliability of the modified sphygmomanometer test to assess strength of the lower limbs and trunk muscles after stroke. J Rehabil Med. 2014;46(7):620-8.

30. Martins JC, Teixeira-Salmela LF, Aguiar LT, Souza LAC, Lara EM, Faria CDCM. Assessment of the strength of the trunk and upper limb muscles in stroke subjects with portable dynamometry: a literature review. Fisioter Mov. 2015;28(1):169-86.

31. Martins JC, Aguiar LT, Lara EM, Moura JB, Souza LAC, Teixeira-Salmela LF, Faria CDCM. Assessment of the strength of the lower limb muscles in subjects with stroke with portable dynamometry: a literature review. Fisioter Mov. 2016;29(1):193-208.

32. Kellar SP, Kelvin E. Muro's statistical methods for health care research. 5th ed. Philadelphia: LWW; 2005.

33. Feigin VL, Forouzanfar MH, Krishnamurthi R, Mensah GA, Connor M, Bennett DA, et al. Global and regional burden of stroke during 1990-2010: findings from the Global Burden of Disease Study 2010. Lancet. 2014;383(9913):245-54.

34. Ada L, Canning CG, Low SL. Stroke patients have selective muscle weakness in shortened range. Brain. 2003;126(3): 724-31.
35. Billinger SA, Arena R, Bernhardt J, Eng JJ, Franklin BA, Johnson CM, et al. Physical activity and exercise recommendations for stroke survivors: a statement for healthcare professionals from the American Heart Association/American Stroke Association. Stroke. 2014;45(8):2532-53.

36. Kwakkel G, Kollen BJ. Predicting activities after stroke: what is clinically relevant? Int J Stroke. 2013;8(1):25-32.

37. Santiago MC, Coyle CP, Kinney WB. Aerobic exercise effect on individuals with physical disabilities. Arch Phys Med Rehabil. 1993;74(11):1192-8.

38. Silva PB, Antunes FN, Graef P, Cechetti F, Pagnussat AS. Strength training associated with task-oriented training to enhance upper-limb motor function in elderly patients with mild impairment after stroke: a randomized controlled trial. Am J Phys Med Rehabil. 2015;94(1):11-9.
Received in 01/22/2019

Recebido em 22/01/2019

Recibido en 22/01/2019

Approved in 01/07/2020 Aprovado em 07/01/2020 Aprobado en 07/01/2020 